\title{
IDENTIFIKASI TAMBAHAN Trichoderma PADA PISANG DARI INDUK TERBAIK YANG TELAH MENDAPAT PERLAKUAN TRICHODERMA UNTUK MENEKAN Layu Fusarium.
}

\author{
Bukhari $^{(1)}$, Nuryulsen Safridar ${ }^{(2)}$ \\ Program Studi Agroteknologi Universitas Jabal Ghafur
}

\begin{abstract}
ABSTRAK
Tujuan penelitian adalah untuk mengetahui Identifikasi tambahan Trichoderma pada tanaman pisang dari induk terbaikuntuk mengendalikan layu fusarium terhadap pertumbuhan tanaman pisang (Musa paradeciaca)serta ada tidaknya interaksi antara kedua faktor yang dicobakan.

Penelitian ini dilaksanakan di desa Dayah kecamatan Keumala Kabupaten Pidie, Provinsi Aceh, pada bulan November 2017 sampai dengan Juni 2018. Penelitian ini menggunakan Rancangan Acak Kelompok (RAK) 4 x 4 dengan 2 ulangan. Faktor 2Indukan Hasil Perlakuan Terbaik dari dua penelitian sebelumnya, yang masing-masing disimbulkan dengan $\mathrm{A}_{1}$ (Barangan +200 gram trcoderma $8 \mathrm{~kg}$ pupuk kandang), $\mathrm{A}_{2}$ (Barangan+200 gram tricoderma $12 \mathrm{~kg}$ pupuk kandang), $\mathrm{A}_{3}$ (Geupok+200 gram trcoderma $8 \mathrm{~kg}$ pupuk kandang), $\mathrm{A}_{4}$ (Geupok+200 gram trcoderma $12 \mathrm{~kg}$ pupuk kandang). Faktor pemberian Trichoderma sp juga terdiri dari 4 taraf yaitu $\mathrm{T}_{0}$ (Tanpa tambahan Trichoderma sp ), $\mathrm{T}_{1}$ (ditambah 200 gram/lubang tanam), $\mathrm{T}_{2}$ (ditambah 400 gram/lubang tanam) $\mathrm{T}_{3}$ (ditambah 600 gram/lubangtanam). Parameter yang diamati : Instesitas Serangan, tinggi tanaman pada umur 40, 80 dan 120 HST, jumlah daun dan lilit batang Indukan tidak berpengaruh nyata terhadap intensitas serangan penyakit layu fusarium, terhadap semua parameter yang diamati. Trichoderma tidak berpengaruh nyata terahadap terhadap intensitas serangan penyakit layu fusarium, tinggi tanaman jumlah daun dan lingkaran batang tanaman pisang terhadap semua parameter yang diamati. Terdapat interaksi yang nyata antara 2 indukan terbaik dan Trichoderma terhadap lingkaran batang tanaman pisang, namun tidak berpengaruh nyata terhadap parameter lainya. Kombinasi terbaik dijumpai pada perlakuan $\mathrm{A}_{2} \mathrm{~T}_{3}$ (barang dengan dosis Trichoderma 0.50 gram).
\end{abstract}

Kata kunci : Trichoderma, layu fusarium dan tanaman pisang.

\section{Pendahuluan}

\section{Latar Belakang}

Pisang (Musa Paradisiaca L) diduga hasil persilangan alami dari pisang liar dan telah mengalami domistikasi. Para ahli botani memastikan daerah asal tanaman pisang adalah india, Jazirah malaya dan filipina. Penyebaran tanaman pisang dari daerah asal ke berbagai wilayah negara di dunia terjadi mulai tahun 1000 SM. Pisang merupakan salah satu dari berbagai jenis buah-buahan tropis yang berada dan banyak di kembangkan di indonesia. Syarat tumbuh yang toleran dalam lingkungan yang luas dan juga teknik budi daya yang relatif mudah membuat pisang banyak di budidayakan. Dari segi harga,pisang termasuk komoditas yang memiliki harga yang relatif stabil sehingga lebih memberikan jaminan keuntungan (Stuver,1987).

Budidaya pisang saat ini di Aceh mengalami penurunan hasil, hal ini dikarenakan berbagai kendala yang dihadapi oleh petani dari sumber daya manusia yang tidak memahami dengan benar dalam mengendalikan penyakit yang sering mengakibatkan tanaman mati, tidak tersedianya varietas unggulan, dan menguasai teknologi yang masih kurang mendapatkan informasi yang lebih luas. 
Menurut cahyono (2000), salah satu ukuran keberhasilan usaha agribisnis pisang berawal dari benih yang berkualitas dari varietas unggul. Varietas unggul merupakan salah satu komponen penting untuk mendukung keberhasilan usaha tani buah yang dapat meningkatkan pendapat petani buah. Pada umumnya perbanyakan tanaman pisang masih dilakukan secara tradisional oleh masyarakat seperti menanam anakan yang sudah dewasa, atau anakan yang sudah besar. Pada umumnya sistem perbanyakan ini perkembangan anakan akan stagnasi, perkembangannya bahkan pada kondisi tanah yang kering dan kurang air yang akan tumbuh berkembang biasanya tunas samping. Pada budidaya tanaman pisang benih dapat diperoleh dari perbanyakan belahan bonggol dari tanaman yang sudah dipanen dan dengan memastikan titik tumbuh yang dihasilkan dari perbanyakan secara konvensional yang sehat,mudah dan murah. Mulai dari persiapan benih sampai tanam di lapangan diperlukan waktu 2,5-3 bulan.

Akhir-akhir ini hampir semua varietas pisang mengalami serangan penyakit layu Fusarium yang rata-rata mengakibatkan kematian dan penurunan produksi tanaman pisang, penyakit layu Fusarium Oxysporium Cubense yang berkembang begitu cepat dam mampu menginfeksi rumpun-rumpun pisang sehingga mengakibatkan kerugian yang cukup besar bagi petani pisang. Jamur Fusarium Oxysporium menyerang jaringan empelur batang melalui akar yang luka. Batang yang terserang mongering dan berubah warna menjadi kecoklatan, tepi daun menjadi kuning tua atau layu, tangkai daun patah dibagian pangkal. Kadangkadang lapisan luar batang terbelah mulai dari permukaan tanah. Tanaman yang terserang tidak mampu berbuah atau buahnya tidak berisi.

Trichoderma sp merupakan agen antagonis yang dapat berperan menekan aktifitas phatogen tumbuhan dari golongan jamur. Agen antagonis pathogen tumbuhan adalah mikroorganisme yang mengintervensi aktifitas pathogen dalam menimbulkan penyakit, agens tersebut tidak dapat mengejar inang yang telah masuk kedalam jaringan tanaman, efektifitasnya dapat dilihat dengan tidak berkembangnya penyakit tersebut. Proses antagonis Trichoderma sp terhadap pathogen tular tanah yang bekerja dengan cara parasitisme, kompetisi dan antibiosis.

Bibit jenis pisang yang telah berinteraksi dengan Trichoderma sp diprediksikan dapat menekan serangan penyakit layu fusarium, namun prediksi tersebut harus direalisasikan melalui suatu penenelitian.

Diharapkan penggunaan agen hayati Trichoderma sp.efektif untuk melawan serangan penyakit layu sehingga Padang Tiji dapat kembali menjadi daerah centra produksi pisang yang mampu memasok kebutuhan lokal pisang ke seluruh daerah di Aceh. Penggunaan agen hayati ini merupakan salah satu cara pengembanmgan pertanian organik yang ramah lingkungan sekaligus mengurangi penggunaan pestisida sintetis, sehingga dapat memelihara dan menjaga lingkungan agar tetap stabil dan lestari

\section{Tujuan Khusus}

Penelitian ini bertujuan untuk mengetahui apakah asal bibit dan aplikasi agen hayati trichoderma $\mathrm{sp}$ dapat menekan serangan penyakit layu Fusarium oxysporum pada tanaman pisang ( Musa sapientum L. ) dan kombinasi mana sajakah yang dapat berinteraksi dengan agen hayati trichoderma sp dalam menekan serangan penyakit layu fusarium..

\section{Manfaat Penelitian}

Adapun manfaat daripenelitian ini adalah dapat dijadikansebagai dasar penelitianlebih lanjut untuk mengetahui pengaruh pemberian agen hayati 
trichoderma sp dari baik an bibit pisang dari induk terhadap laju pertumbuhanbibit pala, sekaligus sebagai bahan informasi bagi instasi terkait.

\section{Rumusan Masalah}

1. Apakah bibit pisang yang berasal dari induk yang telah di apliakasi tricoderma dapat melawan serangan penyakit layu fusarium

2. Apakah varietas berpengaruh terhadap asal bibit dalam melawan serangan penyakit layu fusarium

3. Apakah ada interaksi antara bibit pisang dan tricoderma terhadap pertumbuhan pisang pada tahap melawan serangan penyakit layu fusarium.

\section{Hipotesis}

1. Diduga pemilihan induk terbaik mampu menekan layu fusarium pada tanaman pisang

2. Diduga penambahan trichoderma mamapu menekan layu fusarium pada tanaman pisang

3. Diduga terdapat interaksi antara penambahan trichoderma dan induk pisang trichoderma untuk menekan layu fusarium pada tanaman pisang.

\section{Metode Penelitian}

\section{Tempat dan Waktu}

Penelitian dilaksanakan di Desa Dayah Keumala pada yang sudah terkontaminasi penyakit Layu Fusarium Kabupaten Pidie, berlangsung dari bulan Maret 2017 sampai dengan.

\section{Bahan dan Alat Bahan}

Bahan - bahan yang dipakai dalam penelitian ini adalah bibit pisang dari 4 Induk kombinasi terbaik dalam mengendalikan penyakit fusarium dari penelitian tahun ke 2 yang telah mempunyai ketinggian $1 \mathrm{~m}$, beras, pupuk kandang, Trichoderma sp, bakteri Pseudomonas fluorescens,serta bahan-bahan pendukung lainnya yang diperlukan seperti kawat beronjong.

Alat

Alat-alat yang digunakan dalam penelitian ini adalah parang, cangkul, pisau, garu, timba, gembor (alat penyiram), tali, timbangan, Papan pengamat, Alat tulis menulis dan alat-alat lain yang diperlukan.

\section{Rancangan Penelitian}

Penelitian ini menggunakan

Rancangan Acak kelompok (RAK ) Faktorial dengan 2ulangan, faktor yang diteliti yaitu 4 kombinasi terbaik dari hasil penelitian tahun ke 2 pisang yang disimbulkan dengan (A) yaitu

Faktor 4 Indukan Hasil Perlakuan Terbaik pada Tahun kedua

A1= Indukan Barangan diberikan200 gram trcoderma $8 \mathrm{~kg}$ pupuk kandang A2 = IndukanBarangan diberikan200 gram trcoderma $12 \mathrm{~kg}$ pupuk kandang A3= IndukanGupok diberikan200 gram trcoderma $8 \mathrm{~kg}$ pupuk kandang A4 = IndukanGupok diberikan200 gram trcoderma $12 \mathrm{~kg}$ pupuk kandang

Faktor pemberian Trichoderma sp juga terdiri dari 4 taraf yaitu T0=Tanpa tambahanTrichoderma $\mathrm{sp}$ (kontrol),

T1=tambahan200 gram/lubang tanam

T2=tambahan400gram/lubang tanam

T3=tambahan600gram/lubang tanam

Dengan demikian terdapat 16 Kombinasi perlakuan dan 2 ulangan sehingga diperoleh 32 satuan percobaan. Tiap satuan percobaan terdiri dari 1 tanaman sampel susunan kombinasi perlakuan.

Model matematis rancangan percobaan ini adalah sebagai berikut: 
Tabel 1. Susunan Kombinasi perlakuan Indukan Terbaik dan Tambahan Trrichoderma sp

\begin{tabular}{|c|c|c|c|c|}
\hline \multirow{2}{*}{$\begin{array}{l}\text { Indukan } \\
\text { Terbaik Dari } \\
\text { Tahun kedua }\end{array}$} & \multicolumn{4}{|c|}{$\begin{array}{c}\text { Pemberian Trichoderma sp } \\
\text { (g/lubang) }\end{array}$} \\
\hline & 0 & 200 & 400 & 600 \\
\hline $\begin{array}{l}\text { Gupok+200 } \\
\text { gram } \\
\text { trcoderma } 8 \\
\text { kg pupuk } \\
\text { kandang }\end{array}$ & $\mathrm{A}_{1} \mathrm{~T}_{0}$ & $\mathrm{~A}_{1} \mathrm{~T}_{1}$ & $\mathrm{~A}_{1} \mathrm{~T}_{2}$ & $\mathrm{~A}_{1} \mathrm{~T}_{3}$ \\
\hline $\begin{array}{l}\text { Gupok+200 } \\
\text { gram } \\
\text { trcoderma } 12 \\
\text { kg pupuk } \\
\text { kandang }\end{array}$ & $\mathrm{A}_{2} \mathrm{~T}_{0}$ & $\mathrm{~A}_{2} \mathrm{~T}_{1}$ & $A_{2} T_{2}$ & $\mathrm{~A}_{2} \mathrm{~T}_{3}$ \\
\hline $\begin{array}{l}\text { Barangan } \\
+200 \text { gram } \\
\text { trcoderma } 8 \\
\text { kg pupuk } \\
\text { kandang }\end{array}$ & $\mathrm{A}_{3} \mathrm{~T}_{0}$ & $\mathrm{~A}_{3} \mathrm{~T}_{1}$ & $\mathrm{~A}_{3} \mathrm{~T}_{2}$ & $\mathrm{~A}_{3} \mathrm{~T}_{3}$ \\
\hline $\begin{array}{l}\text { Barangan } \\
+200 \text { gram } \\
\text { trcoderma } 12 \\
\text { kg pupuk } \\
\text { kandang }\end{array}$ & $\mathrm{A}_{4} \mathrm{~T}_{0}$ & $\mathrm{~A}_{4} \mathrm{~T}_{1}$ & $\mathrm{~A}_{4} \mathrm{~T}_{2}$ & $\mathrm{~A}_{4} \mathrm{~T}_{3}$ \\
\hline
\end{tabular}

\section{Pelaksanaan Penelitian}

Persiapan Lahan dan Lobang Tanam

Pembersihan areal penanaman pisang terutama dilakukan terhadap gulma yang menyebabkan peningkatan kelembaban lahan. Pembersihan juga dilakukan terhadap tanaman keras yang dapat menghambat penetrasi sinar matahari. Lahan yang sudah dibersihkan kemudian dicangkul dengan kedalaman $30 \mathrm{~cm}$ disekeliling lubang tanam agar struktur tanah menjadi lebih gembur sehingga dapat memperbaiki aerasi tanah dan memudahkan tanaman pisang unstuck mengambil unsur hara. Pemasangan ajir dilakukan untuk menandai lobang tanam sesuai dengan satuan percobaan dengan jarak tanam $3 \times 3$ meter. Lobang tanam dibuat dengan ukuran $50 \times 50 \mathrm{~cm}$ dan dalam $50 \mathrm{~cm}$. Jarak antar perlakuan 3 meter dan jarak antar blok 5 meter

\section{Persiapan Bibit Pisang}

Bibit tanaman pisang yang siap tanam diambil dari 4 induk kombinasi hasil penelitian tahun ke 2 .

\section{Penyiapan Agens antagonis Trichoderma} sp

Agens antagonis Trichoderma sp yang telah dikembangbiakan pada media beras dicampur dengan pupuk kandang dengan perbandingan 1kg: $40 \mathrm{~kg}$. Proses pencampuran dimulai dengan meratakan pupuk kandang setebal $10 \mathrm{~cm}$, kemudian ditaburkan Trichoderma sp secara merata diatasnya, setelah itu kembali dilapisi dengan pupuk kadang dan diratakan. Akhir proses pencampuran media telah siap disiram dengan air sampai sedikit basah dan ditutup dengan dedaunan untuk tetap menjaga kelembaban. Setelah 3 hari media diaduk sampai rata dan ditutup kembali. 1 minggu kemudian Trichoderma sp sudah siap diaplikasikan ke dalam lobang tanam sesuai dengan satuan percobaan.

\section{Penanaman dan Aplikasi Trichoderma sp}

Sebelum dilakukan penanaman bibit pisang terlebih dahulu direndam dengan bakteriPseudomonas fluorescens untuk selanjutnya dimasukkan kedalam lobang tanam yang sudah tersedia. Bakteri Pseudomonas fluorescens untuk mencegah perkembangan bakteri penyebab layu bakteri pada tanaman pisang. Dengan konsentrasi $250 \mathrm{ml}$ bakteri pf di campur dengan 10 liter air.Trichoderma sp yang sudah bercampur dengan pupuk kandang diaplikaskan sebagai penutup lobang tanam sesuai dengan satuan percobaan dan selanjutnya ditambah dengan tanah hasil galian pada lobang tanam.

\section{Pemeliharaan}

\section{Penyiraman}

Air digunakan untuk memenuhi kebutuhan bagi pertumbuhan tanaman. Air yang digunakan untuk penyiraman harus bersih agar tidak menimbulkan penyakit bagi tanaman. Penyiraman dilakukan disekeliling lobang tanam. Kebutuhan air disesuaikan dengan keadaan cuaca dilapangan. 


\section{Pengendalian Gulma}

Gulma yang tumbuh dilahan percobaan dibersihkan agar tanaman dapat tumbuh dengan optimal dan mengurangi kompetisi unsur hara antara tanaman pisang dengan gulma. Pembersihan dilakukan dengan menggunakan cangkul, parang dan sabit.

\section{Pengendalian OPT}

Untuk mendapatkan tanaman yang sehat maka perlu dilakukan pencegahan serangan hama, pencengahan ini dilakukan dengan terus melakukan pengamatan perkembangan tanaman dan melihat keberadaan populasi hama pada tanaman. Karena dalam penelitian ini mengamati intensitas serangan penyakit layu Fusarium oxysforum, maka pengendalian hama dilakukan dengan cara fisik dan mekanik agar tanaman tidak terkontaminasi dengan bahan kimia yang dikhawatirkan berpengaruh terhadap perkembangan Trichoderma sp.

\section{Pemupukan}

Kekurangan unsur hara akan menyebabkan produktivitas dan kualitas buah rendah, namun sebaliknya aplikasi pupuk berlebihan menyebabkan pemborosan. Pemupukan bertujuan agar pertumbuhan tanaman optimal, buah yang diproduksi optimum, serta memiliki ukuran, bentuk dan penampilan luar yang baik, serta rasa yang sesuai. Pemupukan dilakukan dengan membuat larikan melingkar disekeliling batang tanaman. Dosis pemupukan yaitu Urea $250 \mathrm{~g} / \mathrm{lobang}$ tanam, SP 36 sebanyak $250 \mathrm{~g} /$ lobang tanam dan KCL 300 g/lobang tanam

\section{Pengamatan}

Parameter yang diamati dalam penelitian ini adalah :

\section{Intensitas Serangan Penyakit Layu Fusariumoxysforum}

Pengamatan Intensitas serangan dilakukan 40, 80 dan 120 hari setelah tanam. Pengamatan dilakukan dengan cara mengamati helaian daun tanaman pisang pada setiap tanaman sampel dan menghitung tingkat serangan penyakit Fusarium oxysforum menggunakan rumus kerusakan mutlak. Hasil pengamatan kemudian dimasukkan kedalam tabel pengamatan sesuai dengan satuan percobaan.

Rumus kerusakan mutlak adalah suatu rumus untuk menilai serangan penyakit yang menimbulkan kerusakan mutlak (tidak dapat sembuh kembali).

Besarnya intensitas serangan dihitung dengan unterstenhofer (1963) sebagai berikut :

$$
I=\frac{a}{a \times b} \times 100 \%
$$

Keterangan :

I : Intensitas Serangan

A : banyaknya contoh (daun,Pucuk, bunga,buah,batang) yang rusak mutlak atau dianggap rusak mutlak

b : banyaknya contoh yang tidak rusak atau tidak menunjukkan gejala serangan

Kategori serangan untuk jenis penyakit adalah sebagai berikut :

- Serangan ringan bila derajat serangan $\leq 11 \%$

- Serangan sedang bila derajat serangan $>11-\leq 25 \%$

- Serangan berat bila derajat serangan > $25-\leq 75 \%$

- Puso bila derajat serangan $>75-$ $100 \%$

\section{Jumlah Daun}

Pengamatan terhadap jumlah daun dilakukan pada umur 40, 80 dan 120 hari setelah tanam dengan cara menghitung jumlah daun yang keluar dari setiap tanaman.

\section{Lingkaran Batang}

Lingkaran batang juga diukur poda ketinggian $75 \mathrm{~cm}$ di aatas permukaan tanah, yang juga diukur pada umur 40, 80 dan 120 hari setelah tanaman.
Hasil Penelitian Dan Pembahasan
Pengaruh 4 Kombinasi Perlakuan Dari 2 Indukan Terbaik Lanjutan Tahun ke Dua 
Intesitas serangan layu fusarium

Hasil analisis ragam pada(Lampiran2, 4 dan 6) menunjukkan bahwa, pengaruh 4 kombinasi perlakuanterbaik lanjutan tahun ke duatidak berpengaruh nyata terhadap intesistas serangan umur 40 dan 120 HST. Rata-rata intesitas serangan layu fusarium terhadap anakan tanaman pisangterserang penyakitpada umur80 dan 120 HST akibat 4 kombinasi perlakuan terbaik lanjutan tahun ke duadapat dilihat pada Tabel 2.

Tabel 2. Rata-rataIntesitas serangan layu fusarium terhadap anakan tanaman pisangTerserang PenyakitUmur 80dan 120 HST akibat duaIndukan terbaik lanjutan tahun ke dua

\begin{tabular}{|c|c|c|}
\hline \multirow{2}{*}{$\begin{array}{l}\text { Indukan Terbaik } \\
\text { lanjutanTahun } \\
\text { Ke dua }\end{array}$} & \multicolumn{2}{|c|}{$\begin{array}{l}\text { Intesitas tanaman } \\
\text { Terserang Penyakit } \\
(\%)\end{array}$} \\
\hline & $80 \mathrm{HST}$ & $120 \mathrm{HST}$ \\
\hline $\mathrm{A}_{1}$ & 4.19 & 6.25 \\
\hline $\mathrm{A}_{2}$ & 1.00 & 2.42 \\
\hline $\mathrm{A}_{3}$ & 3.11 & 4.19 \\
\hline $\mathrm{A}_{4}$ & 1.57 & 4.27 \\
\hline
\end{tabular}

Tahap akhir dari penjaringan indukan terbaik untukmenguji ketahanan kultivar tanaman pisang terhadap layu fusarium setelah ditemukan indukan terbaik pada penelitian ke dua yaitu barangan dan kepok dengan kombinasi pemberian tricoderma yang berbeda.

Pada penelitian ini tidak memberikan pengaruh yang berbeda terhadap instesitas serangan layu fusarium pada tanaman pisang, hal ini diduga fakor lingkungan yang berbeda dari penelitian sebelumnya. Sesuai dengan pendapatJumin (2005), menyatakan bahwa selain faktor luar (lingkungan), pertumbuhan tanaman juga dipengaruhi oleh faktor yang ada didalam tanaman itu sendiri. Tinggi

Hasil analisis ragam pada(Tabel Lampiran8, 10 dan 12) menunjukkan bahwa, pengaruh 4 kombinasi perlakuanterbaik lanjutan tahun ke dua tidak berpengaruh nyata terhadap tinggianakan tanaman pisang pada umur 40, 80 dan 120 HST, Rata-rata tinggi anakan tanaman pisang pada umur 40, 80 dan 120 HST akibat 4 kombinasi perlakuanterbaik lanjutan tahun ke duadapat dilihat pada Tabel 3.

Tabel 3. Rata-rataTinggi anakan dari 2 indukan terbaik tanaman pisangUmur 40, 80, dan 120 HST akibat 4 kombinasi perlakuan terbaik.

\begin{tabular}{|c|c|c|c|}
\hline \multirow{3}{*}{$\begin{array}{c}4 \text { Indukan } \\
\text { Terbaik } \\
\text { lanjutanTahun } \\
\text { Ke dua }\end{array}$} & \multicolumn{3}{|c|}{$\begin{array}{c}\text { Tinggi anakan dari } 2 \\
\text { indukan terbaik tanaman } \\
\text { pisang }(\mathrm{cm})\end{array}$} \\
\hline & 40 & 80 & 120 \\
\hline & HST & HST & HST \\
\hline$\Delta$ & 97.88 & 89.38 & 68.75 \\
\hline $\mathrm{A}_{2}$ & 104.88 & 112.13 & 125.63 \\
\hline 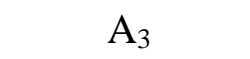 & 89.00 & 94.00 & 90.38 \\
\hline $\mathrm{A}_{4}$ & 84.13 & 89.88 & 85.13 \\
\hline
\end{tabular}

Selain faktor genetik faktor tanah sangat menetukan pertumbuhan tanaman pisang dari masa pertumbuhan vegetative sampai dengan pertumbuhan generative. Tanah yang subur tentu saja akan berpengaruh baik terhadap pertumbuhan tinggi tanaman pisang. Sebaliknya, tanah yang tidak subur akan mengakibatkan tandannya kecil dan pendek. Tanaman pisang menghendaki tanah yang subur. Namun, ditanam di tanah yang kritis pun masih dapat menghasilkan, meski hasilnya kurang memuaskan. Walau tidak menyukai tanah kering, pisang juga tidak menghendaki air yang menggenang terus menerus. Akar tanaman ini memerlukan peredaran udara yang baik di dalam tanah. Tanaman pisang yang tumbuh di tepi sungai yang airnya mengalir kebanyakan tumbuh subur. Tentu saja tanaman pisang yang ditanam di kebun memerlukan drainase yang baik. (Supriadi dan Satuhu, 2004).

Jumlah Daun

Hasil analisis ragam pada(Tabel Lampiran1416 dan 18) menunjukkan bahwa, pengaruh 4 kombinasi perlakuan terbaik lanjutan tahun ke dua pada 2 tidak 
berpengaruh nyata terhadap jumlah daun anakan tanaman pisang pada umur 40,80 dan 120 HST, Rata-rata jumlah daunanakan tanaman pisang pada umur 40,80 dan 120 HST akibat 4 kombinasi perlakuan terbaik lanjutan tahun ke duadapat dilihat pada Tabel 4.

Tabel 4. Rata-ratajumlah daunpisangUmur 40, 80, dan 120 HST akibat 4 Indukan Terbaik lanjutanTahun Ke dua

\begin{tabular}{cccc}
\hline 4 Indukan & & & \\
Terbaik & \multicolumn{3}{c}{ jumlah daunpisang $(\mathrm{cm})$} \\
\cline { 2 - 4 } lanjutanTahun & 40 & 80 & 120 \\
Ke dua & HST & HST & HST \\
\hline $\mathrm{A}_{1}$ & 3.00 & 3.13 & 4.50 \\
$\mathrm{~A}_{2}$ & 3.75 & 5.13 & 6.63 \\
$\mathrm{~A}_{3}$ & 3.75 & 4.88 & 6.00 \\
$\mathrm{~A}_{4}$ & 4.38 & 5.88 & 7.25 \\
\hline
\end{tabular}

Hal ini sesuai dengan pendapat Delvian (2008) menyatakan meningkatnya jumlah daun diduga karena meningkatnya kadar $\mathrm{P}$ tersedia dan juga meningkat kandungan $\mathrm{Al}$ yang dapat bersifat racun bagi tanaman.

Lingkaranan batang

Hasil analisis ragam pada (Tabel Lampiran2, 4 dan 6) menunjukkan bahwa, pengaruh 4 kombinasi perlakuan terbaik lanjutan tahun ke dua tidak berpengaruh nyata terhadap lingkaranan batang anakan tanaman pisang pada umur 4080 dan 120 HST. Rata-rata lingkaranan batanganakan tanaman pisang pada umur 40, 80 dan 120 HST akibat 4 kombinasi perlakuan terbaik lanjutan tahun ke duadapat dilihat pada Tabel 5.

Tabel 5. Rata-ratalingkaranan batang pisangUmur 40, 80, dan 120 HSTAkibat 4 Indukan Terbaik lanjutanTahun Ke dua

\begin{tabular}{cccc}
\hline 4 Indukan & \multicolumn{3}{c}{ lingkaranan } \\
Terbaik & \multicolumn{3}{c}{ batangpisang $(\mathrm{cm})$} \\
\cline { 2 - 4 } lanjutanTahun & 40 & 80 & 120 \\
Ke dua & HST & HST & HST \\
\hline $\mathrm{A}_{1}$ & 20.63 & 21.25 & 17.06 \\
$\mathrm{~A}_{2}$ & 22.50 & 24.44 & 25.25
\end{tabular}

\begin{tabular}{llll}
$\mathrm{A}_{3}$ & 21.63 & 22.25 & 21.50 \\
$\mathrm{~A}_{4}$ & 21.38 & 23.13 & 21.69 \\
\hline
\end{tabular}

Hal ini sesuai dengan pendapat Delvian (2008) menyatakan meningkatnya lingkaranan batang diduga karena meningkatnya kadar $\mathrm{P}$ tersedia dan juga meningkat kandungan $\mathrm{Al}$ yang dapat bersifat racun bagi tanaman.

\section{Pengaruh Pemberian Trichoderma}

Intesitas serangan layu fusarium

Hasil analisis ragam pada(Lampiran2, 4 dan 6) menunjukkan bahwa, pengaruh pemberian Trichodermapada anakan dari 2 indukan terbaik tanaman pisang terhadap intesitas serangan layu fusarium berpengaruh tidak nyata pada umur 80 dan 120 HST,Rata-rataintesitas serangan layu fusarium terhadap anakan tanaman pisang terserang penyakit pada umu80 dan 120 HST akibat pemberianTrichodermadapat dilihat pada Tabel 6 .

Tabel 6. Rata-rataIntesitas serangan layu fusarium terhadap anakan tanaman pisang Terserang Penyakit Umur 80, dan 120 HST akibat Pemberian Trichoderma sp.

\begin{tabular}{ccc}
\hline \multirow{2}{*}{$\begin{array}{c}\text { Pemberian } \\
\text { Trichoderma }\end{array}$} & \multicolumn{2}{c}{$\begin{array}{c}\text { Intesitas tanaman } \\
\text { Terserang Penyakit }(\%)\end{array}$} \\
\cline { 2 - 3 } & $80 \mathrm{HST}$ & $120 \mathrm{HST}$ \\
\hline $\mathrm{T}_{0}$ & 1,45 & 3,82 \\
$\mathrm{~T}_{1}$ & 2,34 & 3,62 \\
$\mathrm{~T}_{2}$ & 3,02 & 4,96 \\
$\mathrm{~T}_{2}$ & 3,06 & 4,73 \\
\hline
\end{tabular}

Hal ini sesuai dengan pendapat Cook dan Barker (2003), bahwa salah satu faktor yang menentukan keberhasilan penggunaan jamur antagonis dalam pengendalian biologis adalah banyaknya populasi jamur antagonis yang diinokulasikan kedalam tanah. Dalam hal ini dapat dilihat, bahwa semakin tinggi dosis biakan jamur $\mathrm{T}$. harzianum dalam tanah, semakin lambat terlihat gejala awal penyakit, seperti pada perlakuan F. Sebaliknya semakin rendah dosis biakan jamur T. harzianum dalam tanah, semakin cepat terlihat gejala awal 
penyakit layu oleh Fusarium oxysporum f.sp capsici. Gejala penyakit paling cepat muncul pada perlakuan A $(0 \mathrm{~g} / \mathrm{kg}$ tanah atau kontrol) disebabkan karena tidak adanya jamur antagonis dalam tanah, sehingga jamur patogen berkembang dengan cepat dan langsung menyerang tanaman, sesuai dengan pendapat Sastra hidayat (2000) bahwa jika pada tanah steril diberikan jamur patogen, maka jamur tersebut akan menyebar lebih cepat dan dengan serangan yang lebih tinggi karena tidak adanya jamur antagonis di dalam tanah yang dapat menghambat pertumbuhan dan perkembangan jamur patogen tersebut.

Tinggi Anakan

Hasil analisis ragam pada(Tabel Lampiran8, 10 dan 12) menunjukkan bahwa, pengaruh pemberian trichoderma pada anakan dari 2 indukan terbaik tanaman pisang terhadap tinggi tanamantidak berpengaruh nyata pada umur 40, 80 dan 120 HST. Rata-rata tinggi tanamananakan dari 2 indukan terbaik tanaman pisang pada umur 40, 80 dan 120 HST akibat pemberian trichoderma dapat dilihat pada Tabel 7.

Tabel 7. Rata-rataTinggi anakan dari 2 indukan terbaik tanaman pisangUmur 40, 80, dan 120 HST akibat Pemberian trichoderma sp.

\begin{tabular}{cccc}
\hline \multirow{2}{*}{ Pemberian } & \multicolumn{3}{c}{ Tinggi tanaman $(\mathrm{cm})$} \\
\cline { 2 - 4 } Trichoderma & 40 & 80 & 120 \\
& HST & HST & HST \\
\hline \multirow{3}{*}{$\mathrm{T}_{0}$} & 82.5 & 84. & \\
& 0 & 63 & 87.88 \\
$\mathrm{~T}_{1}$ & 90.3 & & \\
& 8 & 93.75 & 93.63 \\
$\mathrm{~T}_{2}$ & 110. & & \\
$\mathrm{~T}_{2}$ & 92.88 & 107.38 & 84.13 \\
& & & \\
\hline
\end{tabular}

Tahap akhir dari penjaringan agensia untuk pengendali hayati, setelah ditemukan agensia hayati pada penelitian ke dua yang berpotensi dan lolos masa ujinya, adalah pemformulaan. Formulasi adalah campuran antara biomassa agen hayati dan bahan- bahan yang dapat meningkatkan efektivitas dan kemampuan hidup agens hayati. Adanya pemformulaan yang dilakukan terhadap agensia hayati ditujukan untuk mengatasi permasalahan atau kendala di lapang, sehingga agensia hayati tersebut mampu bekerja dengan kinerja yang tetap dapat dipertahankan baik. Pemformulaan dalam hal ini memberikan perlindungan kepada agensia hayati untuk dapat lebih bertahan hidup didalam kondisi lingkungan yang kurang menguntungkan (Soesanto, 2008).

Jumlah Daun pisang

Hasil analisis ragam pada(Tabel Lampiran14, 16 dan 18) menunjukkan bahwa, pengaruh pemberian trichoderma pada anakan dari 2 indukan terbaik tanaman pisang tidak berpengaruh nyata terhadap pertumbuhan jumlah daunterhadap anakan dari 2 indukan terbaik tanaman pisang pada umur 40, 80 dan 120 HST.Rata-rata jumlah daun pada umur 40, 80 dan 120 HST akibat pemberian trichoderma dapat dilihat pada Tabel 8.

Tabel 8. Rata-rataTinggi anakan dari 2 indukan terbaik tanaman pisangUmur 40, 80, dan 120 HST akibat Pemberian trichoderma sp.

\begin{tabular}{cccl}
\hline \multirow{2}{*}{ Pemberian } & \multicolumn{4}{c}{ Tinggi } & tanaman $(\mathrm{cm})$ \\
\cline { 2 - 4 } Trichoderma & 40 & 80 & 120 \\
& HST & HST & HST \\
\hline & \multicolumn{4}{c}{4.5} \\
$\mathrm{~T}_{0}$ & 3.38 & 0 & 6.00 \\
$\mathrm{~T}_{1}$ & 3.63 & 5.13 & 6.75 \\
$\mathrm{~T}_{2}$ & 3.88 & 5.00 & 4.88 \\
$\mathrm{~T}_{2}$ & 4.00 & 4.38 & 6.75 \\
\hline
\end{tabular}

Hal ini diduga bahan organik didalam tidak mencukupi untuk tahap awal sebagai makanan dasar agar dapat beradaptasi pada ekosistem yang baru. Agen antagonis yang diintroduksikan ke dalam tanah memerlukan bahan organik sebagai makanan dasar agar dapat beradaptasi pada ekosistem yang baru dan mengatasi resistensi dari mikroflora tanah (Weaver, 2005). Bahan organik juga 
berperan sebagai sumber energi dan makanan mikroba tanah sehingga dapat meningkatkan aktivitas mikroba tersebut dalam penyediaan hara tanaman. Jadi penambahan bahan organik disamping sebagai sumber hara bagi tanaman, sekaligus sebagai sumber energi dan hara bagi mikroba (Simanungkalit et al., 2003). Lingkaranan Batang Pisang

Hasil analisis ragam pada(Tabel Lampiran20, 22 dan 2) menunjukkan bahwa, pengaruh pemberian trichoderma pada anakan dari 2 indukan terbaik tanaman pisang tidak berpengaruh nyata terhadap pertumbuhan lingkaranan batang anakan dari 2 indukan terbaik tanaman pisang pada umur 40, 80 dan 120 HST. Rata-rata jumlah daunanakan tanaman pisang pada umur 40, 80 dan 120 HST akibat pemberian trichoderma dapat dilihat pada Tabel 9.

Tabel 9. Rata-rataLingkaranan batang pisangUmur 40, 80, dan 120 HST akibat Pemberian trichoderma sp.

\begin{tabular}{|c|c|c|c|}
\hline \multirow{2}{*}{$\begin{array}{l}\text { Pemberian } \\
\text { Trichoderma }\end{array}$} & \multicolumn{3}{|c|}{$\begin{array}{l}\text { Lingkaranan batang pisang } \\
(\mathrm{cm})\end{array}$} \\
\hline & $\begin{array}{c}40 \\
\mathrm{HST}\end{array}$ & $\begin{array}{c}80 \\
\text { HST }\end{array}$ & $\begin{array}{l}120 \\
\text { HST }\end{array}$ \\
\hline & \multicolumn{3}{|c|}{21} \\
\hline $\mathrm{T}_{0}$ & 20.19 & 00 & 21.00 \\
\hline $\mathrm{T}_{1}$ & 21.56 & 22.88 & 23.31 \\
\hline $\mathrm{T}_{2}$ & 22.94 & 24.75 & 18.06 \\
\hline $\mathrm{T}_{2}$ & 21.44 & 22.44 & 23.13 \\
\hline
\end{tabular}

Secara statistic tidak berpengaruh nyata namun perlakuan tanpa Trichoderma sp menghasilkan jumlah daun yang paling rendah dibandingkan dengan jumlah daun pada perlakuan Trichoderma sp yang cenderung meningkat sejalan dengan meningkatnya dosis Trichoderma $\mathrm{sp}$ dikarenakan jamur ini selain dapat digunakan sebagai biokontrol terhadap serangan pathogen fusarium oxysporum juga dapat berperan sebagai pupuk biologis (Hersanti, 2000).

\section{Pengaruh Interaksi \\ Lingkaranan Batang}

Hasil analisis ragam pada Tabel (Tabel Lampiran16) menunjukkan bahwa, terdapat interaksi yang nyata antara4 kombinasi perlakuan terbaik lanjutan tahun ke dua danTrichoderma sp pada umur 80 HST, serta berpengaruh tidak nyata pada umur 40 dan 120 HSTterhadap lingkaran batang tanaman pisang.Rata-ratalingkaranan batang anakan tanaman pisang terserang penyakit umur 120 HST akibat interaksi antara4 kombinasi perlakuan terbaik lanjutan tahun ke dua danTrichoderma dapat dilihat pada Tabel 8 .

Tabel 8. Rata-rata Lingkaranan batang terhadap anakan tanaman pisang Terserang PenyakitUmur 80 HSTakibat Interaksi 4 kombinasi perlakuan terbaik lanjutan tahun ke dua danTrichoderma sp.

\begin{tabular}{cc}
\hline Kombinasi & Lingkaranan Batang \\
\cline { 2 - 2 } Perlakuan & 80 HST \\
\hline $\mathrm{A}_{1} \mathrm{~T}_{0}$ & $21.5 \mathrm{ab}$ \\
$\mathrm{A}_{1} \mathrm{~T}_{1}$ & $26.5 \mathrm{ac}$ \\
$\mathrm{A}_{1} \mathrm{~T}_{2}$ & $23 \mathrm{ac}$ \\
$\mathrm{A}_{1} \mathrm{~T}_{3}$ & $14 \mathrm{a}$ \\
$\mathrm{A}_{2} \mathrm{~T}_{0}$ & $18 \mathrm{a}$ \\
$\mathrm{A}_{2} \mathrm{~T}_{1}$ & $19.5 \mathrm{a}$ \\
$\mathrm{A}_{2} \mathrm{~T}_{2}$ & $33 \mathrm{ai}$ \\
$\mathrm{A}_{2} \mathrm{~T}_{3}$ & $27.25 \mathrm{a}$ \\
$\mathrm{A}_{3} \mathrm{~T}_{0}$ & $20.5 \mathrm{a}$ \\
$\mathrm{A}_{3} \mathrm{~T}_{1}$ & $23.5 \mathrm{a}$ \\
$\mathrm{A}_{3} \mathrm{~T}_{2}$ & $19.5 \mathrm{a}$ \\
$\mathrm{A}_{3} \mathrm{~T}_{3}$ & $25.5 \mathrm{ae}$ \\
$\mathrm{A}_{4} \mathrm{~T}_{0}$ & $24 \mathrm{ad}$ \\
$\mathrm{A}_{4} \mathrm{~T}_{1}$ & $22 \mathrm{a}$ \\
$\mathrm{A}_{4} \mathrm{~T}_{2}$ & $23 \mathrm{a}$ \\
$\mathrm{A}_{4} \mathrm{~T}_{3}$ & $23 \mathrm{a}$ \\
\hline $\mathrm{BNJ} 0,05$ & 54,95 \\
\hline Ker
\end{tabular}

Keterangan : Angka yang diikuti huruf yang sama pada kolom yang sama berbeda tidak nyata pada taraf $\alpha=5 \%$ (uji BNJ)

Dari Tabel 8 dapat dijelaskan bahwa, rata-rata lingkaranan batang anakan tanaman pisangterbesar pada umur 80 HST, dijumpai pada kombinasi perlakuan 
A2T3varietas (kepok dengan dosis Trichoderma 0.50 gram) yaitudengan nilai $27,25 \mathrm{~cm}$, yang berbeda nyata dengan perlakuan lainnya. Sedangkan lingkaranan batang anakan tanaman pisangterendah dijumpai pada kombinasi A2T3dengan nilai yaitu $14 \mathrm{~cm}$.

Sesuai dengan pendapat (Afrizal 2010), hal ini disebabkan karena terjadinya kompetisi antara F. oxysporum dengan Trichoderma sp dalam tanah. Trichoderma sp memiliki kemampuan untuk menghancurkan selulosa, zat pati, lignin, dan senyawa-senyawa organik yang mudah larut seperti protein dan gula.

Hubungan antara interaksi 4 kombinasi perlakuan terbaik dan Trichoderma sp terhadap lingakaran batang tanaman pisang dapat dilihat pada gambar berikut:

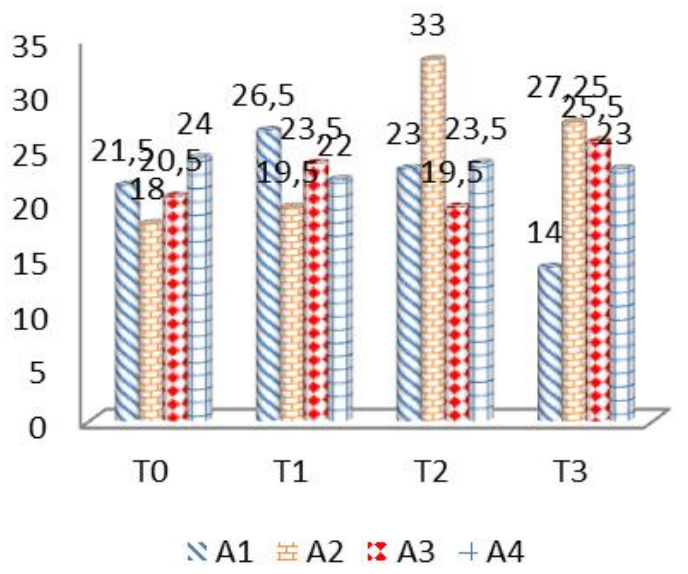

Gambar 1. Histogram Lingkaranan batang anakan tanaman pisang akibat Interaksi Pengaruh 4 kombinasi Perlakuan terbaik dan Trichoderma sp

Gambar 1 dapat di lihat bahwa, lingkaran batang anakan tanaman pisang akibat pengaruh interaksi 4 kombinasi perlakuan terbaik dan Trichoderma sp pada penelitian ini terdapat pada kombinasi perlakuan A2T3 (Kepok dengan dosis Trichoderma 0.50 gram).

Peningkatan pertumbuhan lingkaran batang anakan pisang yang terjadi diduga ada hubungannya dengan pengaruh ketahanan kultivar pisang kapok yang diberikan oleh Trichoderma sp. sebagai perlakuan. Pernyataan tersebut didukung oleh Yedidia et al. (2009), bahwa Trichoderma sp. mampu meningkatkan pertumbuhan tanaman, meningkatkan daya serap mineral aktif, dan nutrisi lainnya dari dalam tanah. Sesuai dengan penelitian Susanto et. al. (2004) bahwa, Trichoderma sp. mampu memacu pertumbuhan tanaman tomat dan tembakau dengan berat kering masing-masing meningkat sekitar 213-275\% dan 259-318\%. Hal ini diduga bahwa ekstrak jamur antagonis mampu mempunyai mekanisme PGPF (Plant Growth Promoting Fungi). Pernyataan tersebut telah dibuktikan pada hasil penelitian Wirastaningjati (2006), bahwa jamur Trichoderma sp. dari rizosfer pisang dilaporkan telah mampu meningkatkan pertumbuhan sehingga selisih tinggi tanaman yang dicapai yaitu $46,74 \mathrm{~cm}$ pada perlakuan pemberian isolat Trichoderma sp. dua minggu sebelum tanaman

\section{Kesimpulan Dan Saran \\ Kesimpulan}

1. Indukan tanaman pisangtidak berpengaruh nyata terhadap intensitas serangan, tinggi tanaman jumlah daun dan lingkaran batang.

2. Trichoderma tidak berpengaruh nyata terahadap terhadap intensitas serangan, tinggi tanaman jumlah daun dan lingkaran batang.

3. Terdapat interaksi yang nyata antara kombinasi 2 indukan terbaik dan Trichoderma terhadap lingkaran batang tanaman pisang, namun tidak berpengaruh nyata terhadap parameter lainya. Perlakuan kombinasi terbaik dijumpai pada perlakuan A2T3 (kultivar barangan dandosis Trichoderma 0.50 gram).

\section{Saran}

1. Upaya pengendalian penyakit tanaman sebaiknya menerapkan konsep PHT 
(pengendalian hama terpadu) agar peningkatan produksi dapat tercapai dengan tetap menjaga keseimbangan ekosistem.

2. Perlu adanya sosialisasi lebih lanjut ketingkat petani tentang keuntungan dengan memanfaatkan agen antagonis trichoderma sebagai tujuan untuk menekan penggunaan pestisida sintesis dan menjaga keseimbangan ekosistem lahan pertanaman untuk mendapatkan hasil yang bebas risidu (pestisda kimia) dan ramah lingkungan

3. Perlu dilakukan penelitian lebih lanjut untuk menerapkan salah satu Trichoderma dalam menekan layu fusarium dilapangan.

\section{Daftar Pustaka}

Anonymous, 2008. Budidaya Pisang, Badan Ketahanan Pangan Dan Penyuluhan (BKPP) Banda Aceh.

Anonymous, 2010, Budidaya Tanaman Menggunakan Phonska Petrogenik PT,Petrokimia Gresik. 2010.

Anonymous, 1999, Morfologi tumbuhan. www.google.co.id/morfologi tumbuhan.com. Di akses 20 februari 2011.

Arifin,1993. Pisang yang menguasai pasaran dunia.www.google.co.id/ search?hl=id\&q.digilib.its.ac.id/publ ic/ITS-Undergraduate-12994-

1599100005-Chapter1.pd. Di akses tanggal 19 Februari 2011.

Brady, N.C. 1990, The Nature and Properties of Soil. Mac Millan Publishing Co., New York.

Chesson, A.1997, Plant Degradation by ruminan: parallels with litter decomposition in soil, In Driven by Nature Plant Litter Quality and Decomposition, Department of
Biological Sciences. (Eds Cadisch, G. and Giller, K.E.), pp. 47-66. Wey College, University of London, UK.

Direktorat Gizi, 1979, Kandungan daging pisang. Dalam Soemarno, www.google.co.id/search?pisang. Di akses 20 Februari 2011.

Efendi, S. (2003). Efektifitas Lima Isolat Trichoderma harzianum terhadap Patogen Fusarium oxysporum f.sp. lycopersici Sacc. Secara In Vitro. Skripsi. Fakultas Pertanian. Universitas Andalas. Padang

Hidayah. 2003. Pengaruh Pemberian Pupuk Phonska terhadap Pertumbuhan dan Produksi Rumput Raja (King grass). Departeman Ilmu Nutisi dan Makanan Ternak, Fakultas Peternakan. Institut Pertanian (IPB). Bogor.

Jumin. H. B. 2005. Dasar-dasar Agronomi. Raja Grafindo Perseda. Jakarta. Cetakan kelima

Mertikawati, 1999. Pengaruh berbagai pupuk organik terhadap beberapa sifat fisika dan kimia vertisol dan ultisol serta hasil padi gogo. Konggres Nasional VII. HITI. Bandung.

Muslimin dan Azim, 2010. Penolahan dan Pemamfaatan Pisang. Kementerian Pendidikan Nasional Direktorat Jenderal Pendidikan Non formal dan Informal Direktorat Pendidikan Kesetaraan. Jakarta

Prihandana, 2007, Bioethanol Bonggol Pisang, dalam bahan kuliah yefri www.google.search/co.id.pembibita n pisang. Di akses 25 Februari 2011. 
Power, J.F. and Papendick, R.I. 1997, Sumber-sumber organik hara. In Tenologi Dan Penggunaan Pupuk, (Eds Engelstad O.P) (Transl. Didiek Hadjar Goenadi), pp. 752-778. Gadjah Mada University Press, Yogyakarta.

Riskomar,1994, Impor pisang dunia meningkat setiap tahun sekitar $9 \%$. www.google.co.id/ search?hl=id\&q. digilib.its.ac.id/public/ITSUndergraduate-12994-1599100005Chapter1.pd. Di akses tanggal 19 Februari 2011.

Redaksi Trubus, 2001, Berkebun Pisang Secara Intensif.. PT Penebar Swadaya. Jakarta.

Rismunandar, 1990. Syarat tumbuh pisang, www.google.co.id/search.morfologi pisang,pdf. Di akses 22 Februari 2011.

Rahmawati, M. \& Hayati, E., 2013. Pengelompokan Berdasarkan Karakter Morfologi Vegetatif Pada Plasma Nutfah Pisang Asal Kabupaten Aceh Besar. Jurnal Agrista, 17(3), pp. 111-118.

Rosdiana, 2009, Manfaat bonggol pisang. www.google.co.id/search.morfologi pisang.pdf Di akses 22 Februari 2011.

Salisbury DanRoss, 1995, Faktor pertumbuhan tanaman. http://www.google.co.id/search?q=p engaruh+pupuk+terhadap+pertumbu han+bibit\&hl. Di akses 01 Maret 2011.

Siregar,T.H., S. Riyadi,L. Nuraeni.2000. Budidaya Pengolahan dan Pemasaran Coklat. Penebar Swadaya, Jakarta.170 hlm.
Suntoro, Syekhfani, E Handayanto dan Sumarno, 2001, Hubungan antara faktor kesuburan tanah dan produksi kacang tanah (Arachis hypogaea) di sentra produksi kacang tanah, jumapolo, Karanganyar, Jawa Tengah. Agrivita. 23 (1) 27-31.

Suprapto , 2008. Teknologi Budidaya Pisang, Balai Besar Pengkajian dan Pengembangan Teknologi Pertanian.Bogor.

Supriyadi dan Satuhu, 2004. Budidaya, Pengolahan dan Prospek Pasar Pisang. PT Penebar Swadaya. Jakarta

Tate III, R.L. 1987. Soil Organic Matter. Biological \& Ecological Effect. John Wiley \& Sons. Inc. New York. Xii + 291p.

Tisdale dan Nelson, 1965, Kandungan dalam pupuk kandang, dalam Jamilah SP, MP. Pengaruh pemberian pupuk kandang dan kelengasan terhadap Perubahan bahan organik dan nitrogen total entisol, Universitas Sumatera Utara.

Warisno,1994, Daerah penanaman pisang cavendis. www.google.co.id/ search?hl=id\&q. digilib.its.ac.id/public/ITSUndergraduate-12994-1599100005Chapter1.pd. Di akses tanggal 19 Februari 2011.

Wiskandar, 2002. Pemanfaatan pupuk kandang untuk memperbaiki sifat fisik tanah di lahan kritis yang telah diteras. Kongres Nasional VII.

Yuanita, 2008.Bioethanol Bonggol Pisang, dalam bahan kuliah yefri www.google.search/co.id.pembibita n pisang. Di akses 25 Februari 2011. 